\title{
ISO における動物福祉
}

\author{
黒澤 努* \\ 大阪大学大学院医学系研究科実験動物医学教室 ₹ 565-0871 大阪府吹田市山田丘 2-2

\section{In ISO/TC194 Biological evaluation of medical devices} \\ Tsutomu Miki Kurosawa \\ The Institute of Experimental Animal Sciences, Osaka University Medical School \\ 2-2 Yamadaoka, Suita-shi, Osaka 565-0871, Japan
}

\section{はじめに}

薬事法の規定では，国民の健康を守るために，医薬品， 医療用具, 医薬部外品抢よび化粧品については厳格な安 全性試験を行うことが，必要とされている。製造に用い られた原料，すなわち医用材料についても安全性試験は 必須である。医薬品では, 生物学的安全性試験だけでな く他の安全性試験に関しても画一的な方法がすでに確立 していて，政府レベルの許認可のためにICH（The International Conference on Harmonisation of Technical Requirements for Registration of Pharmaceuticals for Human Use) が組織された。しかし, 医療機器 (平成 17 年より医療用具が改称された) は金属，高分子化合物 (ポ リマーなど)，生物由来材料など極めて多様な医用材料 で構成されている．したがって生物学的安全性試験に関 しては医薬品と異なる点が多い. 残念ながら，国内には 大手の医療機器会社が少なかったためか, 行政のこの点 の認識は薄く,これまでは医療用具の安全性試験には厳 格なものはなかった，行政指導がそれほど厳しくないこ とと実験動物福祉はかならずしも連動するものとは思わ れないが，医薬品において前臨床試験に関する行政の監 視が強まると, そこに実験動物の専門家の関与が必要と なったという事実がある。実験動物の専門家は単にGLP について詳しいだけでなく国際的な実験動物の現状も把

* E-mail: kurosawa@iexas.med.osaka-u.ac.jp 受付: 2005 年 5 月 24 日 受理: 2005 年 5 月 25 日 (c) 日本環境変異原学会
握していたことから，GLPの普及に伴い我が国の実験動 物福祉も向上していった. 現在我が国に扔いては医療機 器も医薬品と同等に安全性試験等を行う様, 厚生労働省 は行政指導体制を確立した。すなわち独立行政法人医薬 品医療機器総合機構を設立し, 医薬品とともに医療機器 も同等に安全性管理を行うこととしたのである。したが って医薬品の安全性試験に打いて GLP関連省令施行後 に生じた実験動物福祉増進は医療機器業界にも波及する ことが予測される.

こうした状況の中で, 医療機器の生物学的安全性試験 についてはISO/TC194が定めたISO10993に基づいて行 うよう我が国の関連規定が整備され始めた. ISO10993 にはそのPart2において実験動物福祉の文書が完成して おり,この理解が重要である。逆にこの文書はISOにお ける最初の実験動物福祉に関する文書であることから， 実験動物福祉に関する国際的な状況を理解する上で医療 機器産業界だけでなく医薬品業界にも好都合な文書であ る.

ここでは動物福祉と安全性試験に関して，私が作成に 直接関係し, 現在もその改訂作業に関わっている ISO/TC194に扔ける動物福祉に関する国際文書につい て解説する.

\section{背景}

1990 年になり EC 統合が本格化すると, 欧州では各国 間の規制，規則の標準化が始まった。その際に，医療機 器の安全性試験に関しては国際標準を併せて策定するべ きであるとの考えから, ISO において医療機器ならびに

本稿は第 33 回日本環境変異原学会, 第 18 回日本動物実験代替法学会合同学術会議, JEMS \& JSAAE合同シンポジウム 3 「動物福祉と安 全性試験」で発表された。

This paper was presented to the JEMS \& JSAAE combination symposium 3 "Animal welfare and biosafety tests" at the 33rd JEMS annual meeting and the 18th JSAAE annual meeting, 2004. 
医用材料の安全性試験の国際標準が策定されることとな った。

ISO とはそもそも工業製品の国際標準を策定するため に作られた組織だが, 医療機器の中にはあきらかに工業 製品と考えられる製品が多数あり，代表例としてX線撮 影装置，ファイバースコープなどもあり，また外科の鋼 製器具なども国際的に標準化した仕様で生産することが 求められ，個別の国際標準が作られてきた。しかし，医 療機器, 医用材料では生物学的安全性試験が必要となり, これまでの工業製品の仕様の標準とは若干異なる医学的 な国際標準を策定しなければならなくなった.とりわけ， それまでの工業製品の国際標準と医療機器の生物学的安 全性の違いは実験動物を使う点であった。すなわち ISO では多くの工業製品の国際標準化の中で, その性能, 安 全性などを規定する文書は多数作られていたが，生物学 的安全性を求める医療機器では個々の製品について個別 に定めた試験法はあったが，医療機器，医用材料全般に またがる生物学的安全性試験法の文書は存在しなかっ た。したがって多くの試験では実験動物を用いることが なかったため，動物福祉に関する国際標準も作成の必要 がなかったのである。 それが医療機器全般の生物学的安 全性試験の国際標準を作ろうとしたときに顕在化し，欧 米先進国の提案に基づき実験動物福祉検討 WG が設立さ れたのである。

\section{ISO 文書の成立}

ISO 文書 (国際標準) は何らかの標準が必要と認識され ると関係各国に対してNWIP(New Work Item Proposal) が提案され，賛成が得られると TC ( Technical Committee)あるいはSC (Sub Committee)が組織される. 現在 ISO には 188 の TC および546の SCがある。その下 に課題毎にWG(Working Group) が結成され WD (Working Draft)が作成される。これをTC 全体で討議し, $\mathrm{CD}$ (Committee Draft)が作成される。これを各国が持ち 帰り討議した結果をDIS (Draft International Standard) と して，さらに各国に示される。 その際の意見を調整した のち FDIS(Final Draft International Standard)が作成され, 残りの変更可能部分は文言だけとなり，ここにISO 文書 が成立する。こうして医療機器安全性国際標準が作成さ れるには通常 3 年間くらいを要している。現在 ISO/TC194の最も新しい動きとして，医療機器にウシ 由来の材料が多用されていたことから, BSEの安全性に 関してのSCが設立され，活発な議論が始まっている.

ISO/TC194 Biological Evaluation of Medical Devices は関連の文書作成を 15 年間にわたって行っている。我 が国は当初より投票権をもつPメンバーとして参加して いるが，最初の枠組みの中にWG3 Animal Protection Aspectが組み达まれた。医療機器の安全性試験では埋植 試験が欠かせず，実験動物の使用は当たり前であった時
代に，それを保護する国際標準を策定すること自体が我 が国では良く理解できないことであった。そこで私が実 験動物学の専門家として招聘され, ISO 国際標準の実験 動物福祉文書を作成することに関わることとなった。

WG3 の文書は 1992 年に ISO 10993 Part2 Animal Welfare Requirementとしてすでに発効されていて, 我が国 の医療機器の安全性試験の関連文書に“実験動物の福祉 を考慮した試験を行うこと”との表現があるが，それは このISO 文書の反映である。この文書は当時国際的に認 定されていた関連文書である CIOMS（WHOの一部で COUNCIL FOR INTERNATIONAL ORGANIZATIONS OF MEDICAL SCIENCES ; 医の倫理のバイブルとなっ ている，“ヘルシンキ宣言”の作成で著名)の生物科学に おけるガイドラインの精神を多く取り入れた，技術標準 というよりむしろ規範とでもいうべき文書となってい る。

これに対し ECの実験動物愛護団体が中心となって， 改正案が一昨年 (2004 年) 提案され，我が国の反対にも かかわらず，FDISが成立している。この内容には社会 的生活をしている実験動物の単飼の禁止, ウサギの床上 の群飼など, 我が国の安全性試験ではまったく実施され ていない方法も含まれている。ささらに原案では欧米で行 われている実験動物福祉とりわけ実験動物飼育に関する 基準等は欧米の文書を参照するように規定されている. したがって，この改定案が通ると，我が国における医療 機器の生物学的安全性試験の方法は大幅に変更しなけれ ばならないこととなる。また新しい改正案では，当然， 動物実験の前にすべての試験において，代替法をまず考 慮しなければならないこと，および $3 \mathrm{R} の$ 精神による試 験計画の立案が具体的に規定されている，すなわち動物 実験代替法の概念が明確に打ち出されている。“はじめ に”の第 2 項に，医療機器の安全性試験において動物を 用いない試験方法を推進することが謳われている。さら に動物実験は現行の倫理的，科学的原則に基づいて行う ことが示されている.さらに第 3 項には実験動物福祉お よび実験動物飼育環境などに高度な水準で行うことによ り，より確実な安全性試験ができることが記載されてい るのである。

本文の最初は全体的展望から ISO 文書は始まるが，そ の中でも第 2 項目に $3 R s$ が明確に記載されている。また 1992 年の文書からの改正でとくに目につくのが用語の 定義である。これは第 3 節の用語と定義の中に記載され ているが，3.1はAlternative methodであり，これは3Rs に基づく実験方法にて構成されると定義されている。さ らに3Rsはすべて明確に定義されている。すなわち世界 中の最も中心的な工業製品の国際文書にて, 動物実験代 替法の定義がなされ, さらにその要素がReduction, ReplacementおよびRefinementの 3 要素であることが定 義されているのである. 
さらにこの改正案では付属文書 $\mathrm{A}$ の中に 8 項目の解説 が附されているが，その第 2 番目は人道的な動物の看護 と使用の原則となっており，第 3 番目から第 5 番目にか けて入念にReplacement, Reduction およびRefinement が解説されているのである.

\section{結論}

我が国でも動物愛護の精神から, 動物実験に批判的な 意見を持つ国民も多いが，科学者のこれまでの努力にも かかわらず，すべての安全性試験を動物実験なしで行う ことが現在はできない.しかし，それを理由に漫然とこ れまでの試験法を繰り返すことは国際標準として許され なくなり, 動物実験代替法への移行が求められている. 厚生労働省は医療機器の安全性試験に関してはISO 文書 の一部をJIS化して，国内標準と国際標準を一致させる ことを決定している。しかし，我が国には未だ導入され ていない技術を用いた試験法が国際標準となってしまっ ていることに気づく者は少ない.
今後は国際的な標準づくりに専門家が積極的に参加 し, 我が国にも適用可能な安全性試験を国際標準として 提案してゆくことが求められる。とりわけ新しい動物害 験代替法の提案により，国民には安全な医療を提供しつ つ，動物実験の $3 \mathrm{R} の$ 精神に則った安全性試験の実施の 両方が可能となるものと思われる.

こうした我が国に求められる国際化は徐々に法制に及 び始めてきた。 今から 5 年前に改正された動物愛護法は 成立の付带決議として 5 年後の見直しが謳われていた. 最近, 政党間での再改正案の調整が行われ, 今国会に議 員立法として提案される見通しとなっている改正案で は、これまでできるだけ苦痛を軽減する方法 (Refinement)だけが規定されていたが，これに加えて， できるだけ数を少なくし，可能であれば動物実験によら ない方法を用いることが新たに規定されている. 我が国 に㧍ける動物実験代替法の活動がますます活発化する情 勢となってきている. 